\title{
IMPACT OF OCCUPATIONAL HEALTH AND SAFETY REGULATIONS ON THE EMPLOYEE'S DECISION TO TAKE UP EMPLOYMENT
}

doi: $\quad 10.2478 /$ czoto-2019-0018

Date of submission of the article to the Editor: 18/11/2018

Date of acceptance of the article by the Editor: 04/01/2019

\author{
Anna Bazan-Bulanda ${ }^{1}$ - orcid id: 0000-0002-6715-2215 \\ ${ }^{1}$ Czestochowa University of Technology, Poland, anna.bazan-bulanda@wz.pcz.pl
}

\begin{abstract}
Workers' safety in the workplace depends on the compliance of both employees and the employer with applicable regulations. The EU member states in internal law contain regulations in line with EU directives in this area. The author of this study decided to examine whether compliance by the employer with health and safety provisions is an element motivating employees to take up employment. he law applies to both employees and employers, but their content is not affected by any of the parties to the employment relationship. The purpose of the article was to answer the question whether compliance by the employer with health and safety at work rules is an element that influences the employee when making a decision about taking up employment. The method used was the diagnostic survey method and the survey tool. The research was conducted in 102 facilities-enterprises in the Silesian Voivodeship employing at least 20 employees. The respondents were employees within the meaning of the Labor Code who declared knowledge of basic regulations in the field of occupational health and safety. The unambiguous lack of impact of compliance with the health and safety at work regulations by the employer on the decision on employment was indicated by $29.3 \%$ of respondents, while $60.8 \%$ of all respondents declared such an impact. Among the surveyed employees there was a group of undecided people,
\end{abstract}

Keywords: health and safety at work regulations, motivation, employee, employer, employment.

\section{INTRODUCTION}

Occupational health and safety can be the shortcut in which the employer approaches his employee so that during the professional activity the employee is not exposed to health. A man who does his job should also have maximum security. Therefore, the employee has the right to safe and non-threatening work, and the employer should provide him with this. "The working environment exposes a person to many material and intangible harmful factors. Interpersonal relationships between people working in a given organization and the structure of this organization also have a great impact on the health of employees " (Urbańska and Żelazko, 2016). 
The law imposes an obligation on the employer to ensure the safety and hygiene of work for employees in every aspect related to their work.

“The determining factors of workers' quality of employment and occupational health are many and different, including from those of a structural nature (productive sector, size of company, labour organization, type of contract) and contextual (economic cycle, normative regulation ), to those with an institutional dimension (system of labor relations, union participation, collective bargaining, Labor Inspection) and, even, cultural (business management model, preventive training programs and risk assessment)" (Castiblanque and Calatayud. 2018).

To provide employees with safe working conditions, it is necessary to introduce appropriate legal regulations. In art. 153 of the Treaty on the Functioning of the European Union Treaty on European Union (Consolidated version 2016) OJ C 202, 7.6.2016 has the power to adopt directives in the field of safety and health at work. The basic legal act is Directive 89/391 Framework Directive for safety and health at work of $12^{\text {th }}$ June 1989. (OJC 183 z 29.6.1989) Directive 89/391/EEC - OSH "Framework Directive" of 12 June 1989 on the introduction of measures to encourage improvements in the safety and health of workers at work - "Framework Directive". $U$ Member States are required to incorporate the objectives of the Directive into the internal legal order. When transposing EU directives into national law, Member States can adopt stricter rules for the protection of employees. Therefore, legislative requirements in the field of health and safety at work may vary from one EU Member State to another (Strauss-Raats, 2018). The aims of the directives must be implemented, therefore, despite the differences in the detailed regulations in the field of health and safety at work, there is a similarity in the field of work safety between various EU countries (Greer 2018). The main purpose of the directive was to introduce measures to improve the safety and health of workers at work. She defined the obligations of both employers and employees in the field of reducing the number of accidents and occupational diseases in the workplace. The Directive applies to all sectors of activity, both in the public and private sectors (industrial, agricultural, commercial, administrative, services, education, education and culture, entertainment activities, etc.). She introduced the following duties for employers. They must: Ensure the safety and health of employees. This includes assessing and preventing risks, developing general safety rules, and providing appropriate training to employees. Designate a person responsible for preventing risks in the workplace. Take appropriate measures to provide first aid in an emergency, fire fighting and evacuation of workers. Assess risks to specific employees and ensure that appropriate safeguards are applied. Provide employees and their representatives with all relevant information on potential health and safety risks and preventive measures taken. Consult employees and their representatives and engage them in all discussions about health and safety at the workplace. Ensure that every employee receives appropriate health and safety training appropriate to the work they do. According to the directive, every employee responds, if possible, to their own health and safety as well as to the health and safety of their employees. However, special protection should be provided to employees who may be particularly exposed to possible hazards and dangers in the workplace. The Directive does not apply to parts of public services such as the police, armed forces or to specific fields of activity in the field of civil protection services. 
The Framework Directive had to be transposed into national law by the end of 1992 . The effects of its transposition into national legal systems were different in different Member States. This term was binding on countries that are members of the Community. The newly adopted countries' objectives of the directive had to be introduced in their legal systems as part of the adaptation of the existing legal order to EU law.

The main Polish legal act is the Act of $26^{\text {th }}$ June 1974. Labor Code (ie Journal of Laws of 2018, item 917, as amended) in which the entire Tenth Department is devoted to occupational health and safety. In addition to the Labor Code, there are provisions on $\mathrm{OSH}$ in many of the specific regulations regulating individual types of work. These regulations are compliant with European legal norms. This is obvious because every Member State must comply with EU law.

The obligation to adjust OSH regulations to the EU legal order also includes countries that intend to join the European Union. As an example, you can indicate Moldova. In the Annex to the document RECOMMENDATION OF THE EU-REPUBLIC OF MOLDOVA ASSOCIATION COUNCIL COUNCIL NO 1/2017 of 4th August 2017 on the EU-Republic of Moldova Association Program (Official Journal of the European Union L 215/3, 19.8.2017) contained were the priorities of the association program. As part of the priority of Equal Treatment as a medium-term priority, it was pointed out to ensure harmonization with European standards regarding health and safety rules and provisions regulating maternity leave and reconciliation of parental and occupational obligations.

In 2004, the European Commission published a communication (COM [2004] 62) on the practical implementation of the provisions of those directives in the field of $\mathrm{OSH}$, including Framework Directive 89/391 / EEC. This communication states that there is evidence of a positive impact of European rules on national standards in the field of safety and health at work, which is the result of both national implementing rules and their practical application in enterprises and public sector institutions.

Overall, the report concludes that European legislation has contributed to the creation of a risk prevention culture within the European Union and to the rationalization and simplification of national legislative systems. At the same time, however, the report highlights the various shortcomings in the application of the rules that hinder the full use of their potential. There were also cases of instances of infringement proceedings. Specialists and authors dealing with health and safety issues recognize and emphasize the important role of compliance with health and safety rules by all entities under the employment relationship. They point out that compliance with health and safety rules is not only an employee's privilege, but above all an obligation for both the employer and the employee. "The practices of health defense in work settings and the continuous improvement of occupational well-being do not depend merely on norms and processes. If we do not want to limit our interventions to the priority objective of injuries reduction, then we must go beyond the particular technical characteristics of a job: we must lay the groundwork so that the job conditions allow for real self-realization." (Ricci, Chiesi, Bisio, Panari, Pelosi 2016) For this reason, you can not talk about proper, safe working conditions if both sides do not apply to OSH regulations. It should be emphasized that some employees believe that work poses a threat to their health, or reports that they already have work-related illnesses that have caused or exacerbated the work, which is not a result of an accident at work or a work-related illness (Marcinkiewicz et al., 2016). 
Making a decision about employing a particular employer causes various reasons. Often, economic, organizational or prestige related considerations are associated with work in a given company. Researchers of motivation issues usually deal with issues of motivating an employee by the employer, motivational systems applicable at a given employer, etc. These elements depend on the employer. The author of this study decided to examine whether compliance by the employer with health and safety regulations is an element motivating employees to take up employment with a particular employer. It should be noted that the legal provisions apply to both employees and employers, but their content does not affect any party to the employment relationship. In order to formulate an opinion whether the employer's compliance with occupational safety and health rules is an element motivating employees to take up employment with them, the concept of motivation should be clarified. The literature presents many definitions of motivation in a different approach. In this study, only a few terms of this concept have been taken into account due to its limited volume. P. Zimbardo states that "motivation is a general, dynamic concept that helps to explain the processes involved in starting, managing, maintaining and interrupting behavior" (Zimbardo, 2002). E. Aronson, T. Wilson, R. Aker, while presenting the concept of motivation, distinguish between internal motivation and external motivation. Inner motivation (instrinsis motivation) is to engage in some action, because it makes us happy or arouses our interest, not because of external pressure or for external gain. External motivation (extrinsic motivation) is a commitment that results from external pressures or the desire to obtain external benefits rather than our interest (Aronson et al., 1997). Motivation is related to human behavior influenced by both external and internal factors.

"The concept of motivation can be understood in two ways. It can be treated as a relatively constant tendency of a man to achieve specific goals, life tasks and values. This understanding of motivation is directly related to personality psychology. In a narrower sense, motivation is sometimes associated with the concept of the motivational process that underlies a specific, specific human behavior." (Strelau, 2002) From the point of view of psychology, motivation is a process without which it is impossible to achieve the intended goal.

Motivation generally defines phenomena such as: desire, intention, intention, desire for something, interest in something. You can also define it as a psychological process, on which depends, what goals we want to achieve in the future, how much we want to use energy and devote time to it" (Kozłowski, 2010). Therefore, motivation is indispensable for any action. Lack of motivation can lead to cessation of activity by a human being. It is therefore reasonable to examine whether the employer's compliance with $\mathrm{OSH}$ legislation affects the employee's decision to take up employment.

\section{METHODOLOGY OF RESEARCH}

The research was of pilot nature. Their goal was to determine if there was any impact on the employer's compliance with $\mathrm{OSH}$ regulations on the motivation of potential employees.

The aim of the study was to gain knowledge about the impact of the employer's compliance with $\mathrm{OSH}$ regulations on the employment decision. The basic question is: Does the employer's compliance with health and safety regulations affect the decision to employ? 
The study used a diagnostic survey method and a questionnaire technique. An anonymous survey carried out in 102 facilities was used. These were enterprises from the Silesian Voivodeship employing at least 20 employees. Respondents belonged to one of four age groups. Persons aged 25 to 35 constituted $22,5 \%$ of the respondents. The most numerous group were people from the age group 36-45 years $-47 \%$. Respondents aged 46 to 55 constituted $24,5 \%$ of the total responding to survey questions. The least numerous group included persons over 56 years - $6 \%$ of all respondents. All persons participating in the study were employees within the meaning of the regulations. Regulations in the field of $\mathrm{OSH}$ are included in many legal acts. Their knowledge is related to the type of work performed. Therefore, the research concerned only part of the provisions regulated in a general legal act such as the Labor Code. The questionnaire started to check the level of knowledge of employees of $\mathrm{OSH}$ regulations from selected groups: health prophylaxis, accidents at work and personal protection equipment.

\section{RESULTS}

The survey started with a question checking the respondents' knowledge about OSH regulations. All respondents declared that they had information on this subject. Another issue was knowledge of specific provisions. In the question, the respondents had to choose which of the three groups of recipes they know, or indicate others. The respondents could mark any number of answers. None of the respondents declared knowledge of legal regulations outside of the list included in the survey. All employees know the regulations governing medical examinations. The majority $(93,1 \%)$ have knowledge about regulations regarding accidents at work. The smallest survey respondents had $74,5 \%$ of respondents among the provisions referring to personal protective equipment. The distribution of answers to the question about knowledge of legal regulations of accidents in particular age groups is interesting. The legal regulations of accidents at work are mainly known to people who make up the 36-45 age group. They constitute $47,7 \%$ of respondents answering this question positively. The smallest percentage of $5,2 \%$ is made up of people over 56 years old. However, taking into account the total number of respondents divided into age groups, the knowledge of legal provisions in the field of work among people in particular age groups is as follows. In the $25-35$ age group, as many as $95,6 \%$ of respondents know the above regulations. $93,7 \%$ of persons belonging to the age group of $36-45$ years gave a positive answer to the above question. In the group of people aged 46 to 55 , $92 \%$ state that they have knowledge of the regulations relating to accidents. The smallest group of respondents declaring knowledge of the indicated regulations are people over $56-83 \%$. Among the respondents who gave a positive answer to the question about the knowledge of legal norms covering personal protection measures, the largest group were people aged 36-45 - 53, 90\%, and the least numerous persons aged 56 or more. Referring the above answers to all respondents, it should be stated that the knowledge of the above-mentioned provisions is most often declared by people aged between 46 and 55 as many as $88 \%$. From the group of respondents who make up the age group of $36-45,85,5 \%$ state that they know the regulations concerning personal protective equipment. The same opinion was expressed by $66,6 \%$ of people over 56 years old. The smallest knowledge is held by people who are between 25 and 35 years old. Out of this group, 39,1\% gave an affirmative answer to the above question. 
Data on the respondents' knowledge on basic legal regulations in the field of occupational health and safety were necessary to answer the question whether compliance by employers with health and safety provisions affects the decision to employ a given employer.

$60,8 \%$ of all respondents gave a positive answer to this question. On the other hand, the negative response was $29,4 \%$, and no $9,8 \%$ of respondents had any opinion on this topic.

The most numerous group that stated that the employer's compliance with health and safety at work rules affect the decision to employ a given employer are people aged 36-45. A positive response was given by $51,6 \%$ responding positively to this question. Only $4,8 \%$ of all respondents responding positively to the above question are respondents from among 56 persons.

Taking into account the ratio of positive responses in individual age groups to the total number of respondents in a given age group, it can be stated that as many as $76 \%$ of respondents aged 46 to 55 gave a positive answer to the above question. Over half of all respondents aged $35-45(66,6 \%)$ also gave a positive answer. Half of the respondents from the group aged over 56 also declared such an influence. The lowest impact on the motivation for employment was indicated by people aged 25 to 35 $34,7 \%$.

The most numerous group stating that employers' compliance with health and safety at work rules does not affect the decision to employ is made by people aged 36-45$40 \%$ of the total responding negative. However, persons from the youngest group (2535 years) accounted for only $10 \%$ of the total responding to the above question.

In this question, also negative responses were analyzed for all respondents, broken down by age group. In the group of people aged 56 and older, 50\% commented negatively on this topic. Lack of impact of compliance with legal provisions in the field of health and safety at the employer's intention to take up employment was indicated by $43,5 \%$ of all respondents from the $25-35$ age group. Less often, the respondents from the age group of $36-45$ years gave a negative answer to this question. They constituted $27 \%$ of all people in this group. The smallest percentage in the total number of people aged 46-55 stated that compliance with these provisions did not play a role in the employment decision $-20 \%$.

\section{DISCUSSION}

All EU countries must comply with labor safety standards contained in EU directives. By implementing their content to internal law, they can introduce more stringent standards. The Polish legal system as the regulations of the EU state is consistent with EU standards. EU regulations must also be introduced by EU candidate countries in the framework of adapting their legal systems to EU standards. For proper compliance with health and safety regulations it is necessary to know them both by employers and employees. The research was conducted among employees in the understanding of labor law. An employee in accordance with the regulation of art. 2 of the Labor Code is a person employed under a contract of employment, appointment, election, appointment or a cooperative employment contract.

The analysis of the results from the conducted research shows that all employees know the rules regarding medical examinations. This is a positive phenomenon, because in the light of existing legal regulations, it is possible to take action to better protect the health of employees based on a good recognition of key problems faced 
by working Poles (Merecz-Kot and Andysz, 2014). Preventive care for workers should include activities aimed at education, assessment and possible modification of risk factors and control of occupational exposure. Secondary prevention should also be implemented, which will include early detection of the first symptoms of diseases, especially cardiovascular health, in employees (Salska et al., 2014). Most $-93,1 \%$ have knowledge about regulations regarding accidents at work. The respondents were least aware of the provisions relating to personal protective equipment. The above results indicate that the issues related to legal norms that cover accidents at work are not indifferent to employees and have knowledge about them regardless of age. The analysis of the above answers allows to conclude that knowledge of the provisions regarding employee liability does not increase in direct proportion to age. The greatest knowledge - more than $80 \%$ have employees in the age range of 36 to 55 years. However, the youngest group of respondents has the least information on this subject. For more than half of the respondents $(60,8 \%)$, the potential employer's compliance with occupational health and safety regulations is a factor influencing the decision to take up employment with him. It is surprising, however, that up to $29,4 \%$ does not matter. Further research should be carried out to be able to diagnose where this indifference comes from. The lack of opinions on this subject among $9,8 \%$ of respondents is also disturbing.

\section{CONCLUSION}

The Polish legal system is compliant with EU standards covering OSH issues. The analysis of the responses obtained from the conducted surveys suggests that employees know the basic legal regulations in the field of occupational health and safety. Not all provisions equally have the same meaning for them. The most important for employees are the rules regarding medical examinations. In addition to the indicated, the norms regulating accidents at work are equally important for the respondents. The last group are standards in the field of personal protection. Knowing the regulations, employees can determine whether their compliance by the employer affects the decision to take up employment with a given employer.

Motivating compliance with regulations affects more than half of respondents, while for about $10 \%$ this has no effect. As indicated in the introduction, the research was of a pilot nature. In the future, the study should be carried out in another EU country. The obtained data will allow to analyze the impact of compliance by the employer with health and safety at work on the employee's decision about employment in a given country. It will be possible to compare the motivation of Polish employees with the motivation of employees from another EU member state.

\section{REFERENCES}

Aronson, E., Wilson, T., Aker, R., 1997. Psychologia społeczna. Serce i umyst. Zysk i S-Ka Wydawnictwo, Poznań.

Greer S.L., 2018. Labour politics as public health: how the politics of industrial relations and workplace regulation affect health. European Journal of Public Health, Vol. 28, Supplement 3.

Kozłowski, W., 2010. Zarządzanie motywacją pracowników. CeDeWu, Warszawa. 
Marcinkiewicz, A., Walusiak-Skorupa, J., Wiszniewska, M., Rybacki, M., Hanke, W., Rydzyński, K., 2016. Challenges to occupational medicine in view of the problem of work-related diseases and the aging of workforce. Directions for firther development and intentional changes in preventive care of employees in Poland. Medycyna Pracy, 67(5):691-700. dx.doi.org/10.13075/mp.5893.00416

Merecz-Kot, D., Andysz, A., 2014. The occupational, family, and health conditions of Polish workers living in urban areas. Medycyna Pracy, 65(6), 785-797. dx.doi.org/10.13075/mp.5893.00109.

Payá Castiblanque, R., Beneyto Calatayud, P., 2018. Intervención sindical y salud laboral en la Unión Europea: dimensiones, cobertura e impacto, methaodos. revista de ciencias sociales,6(2). dx.doi.org/10.17502/m.rcs.v6i2.238

Salska, A., Chiżyński, K., Salski, W., Wiszniewsk,a M., Walusiak-Skorupa, J., 2014. Rare cardiovascular diseases in the context of occupational health care. Medycyna Pracy, 65(6), 847-856. dx.doi.org/10.13075/mp.5893.00003

Strauss-Raats, P., 2018. Temporary safety. Regulating working conditions in temporary agency work. Safety Science 112.

Strelau, J.(red.), 2002. Psychologia. Podręcznik akademicki, tom 3, Jednostka w społeczeństwie $i$ elementy psychologii stosowanej. Gdańskie Wydawnictwo Psychologiczne, Gdańsk.

Urbańska, K., Żelazko, A., 2016. Comparison of exposure to stress and analysis of ways of coping with stress among freight transport and public transport drivers. Medycyna Pracy,67(4), 455-466. doi.org/10.13075/mp.5893.00384.

Zimbardo, P., 2002. Psychologia i życie. Wydawnictwo Naukowe PWN, Warszawa. 